\title{
Determinants of Postponed Cancer Screening
} During the COVID-19 Pandemic: Evidence from the Nationally Representative COVID-19 Snapshot Monitoring in Germany (COSMO)

\author{
André Hajek (1) \\ Freia De Bock ${ }^{2}$ \\ Lena Huebl ${ }^{3}$ \\ Benedikt Kretzler' \\ Hans-Helmut König (D) \\ 'Department of Health Economics and \\ Health Services Research, Hamburg \\ Center for Health Economics, University \\ Medical Center Hamburg-Eppendorf, \\ Hamburg, Germany; ${ }^{2}$ Federal Centre of \\ Health Education, Cologne, Germany; \\ ${ }^{3}$ Department of Tropical Medicine, \\ Bernhard Nocht Institute for Tropical \\ Medicine \& I Department of Medicine, \\ University Medical Center Hamburg- \\ Eppendorf, Hamburg, Germany
}

Purpose: The COVID-19 pandemic is accompanied by various challenges for individual health and the health care system. However, preventive examinations such as cancer screenings should not be postponed during a pandemic. Because nationally representative studies describing postponed cancer screenings and identifying its determinants in Germany are lacking, our aim was to close this gap in knowledge.

Materials and Methods: We used cross-sectional data from the nationally representative online-survey "COVID-19 Snapshot Monitoring in Germany (COSMO)" (wave 17), which was conducted in July 2020. The analytical sample included 974 individuals (mean age was 45.9 years, SD: 16.5 years; 18 to 74 years). The outcome measure was whether cancer screening had been postponed since March 2020 due to the COVID-19 pandemic (no, attended as planned; yes, postponed).

Results: In total, slightly more than $10 \%$ of individuals stated to have postponed cancer screenings between March and July 2020 due to the COVID-19 pandemic, particularly women and individuals aged 30 to 49 years. The likelihood of postponed cancer screening was positively associated with higher affect regarding COVID-19 (OR: 1.65, 95\% CI: 1.162.35 ), whereas it was negatively associated with younger age (eg, 18 to 29 years, OR: 0.17 , 95\% CI: $0.05-0.64$, compared to individuals 30 to 49 years)

Conclusion: Study findings showed that one out of ten individuals postponed cancer screenings during the COVID-19 pandemic. We determined two correlates of them (age and affect regarding COVID-19). Individuals with an increased likelihood of postponed cancer screenings should be specifically addressed.

Keywords: cancer screening, corona-virus, COVID-19, delayed screening, postponed screening; SARS-CoV-2; access to health care; availability of medical care; health care use; health care utilization; health services research; postponed treatment

\section{Introduction}

It is well known that globally cancer is a main driver of mortality. ${ }^{1}$ Numerous types of cancer are positively associated with age. In high-income countries further demographic aging is expected and thereby cancer prevalence will increase. ${ }^{2}$ However, on the contrary survival rates increase steadily by advancement in cancer treatment and prevention. ${ }^{3}$
Department of Health Economics and Health Services Research, Hamburg Center for Health Economics, University Medical Center Hamburg-Eppendorf, Martinistr. 52, Hamburg, 20246, Germany Tel +49407410- 52877

Fax +49 40 74I0- 4026

Email a.hajek@uke.de 
Three types of prevention exist. The aim of primary prevention is to decreasing incidence rates of diseases. Whereas secondary prevention focuses on early detection and immediate treatment of disease. For example, secondary prevention strategies for cancer include colorectal cancer screening, cervical cancer, and mammography screening. Moreover, tertiary prevention refers to preventing the progression of existing conditions.

Worldwide, the World Health Organization established guidelines and criteria for screening procedures. ${ }^{4}$ Numerous countries reimburse cancer screenings if efficacy has been confirmed. In Germany, several voluntary population-based cancer screenings are paid for by statutory health insurances. For women, these screenings include, among other things, an annual genital examination (for those aged 20 years and over), and an annual breast examination (30 years and over). For men, these screenings include, among other things, the examination of the external genital organs and the palpation of the prostate and lymph nodes (for those aged 45 years and over). Further details are provided by the Federal Joint Committee (G-BA) in Germany ${ }^{5}$ or by the Federal Ministry of Health in Germany. ${ }^{6}$ Despite the opportunity to use these services free of charge, screenings are often underused. ${ }^{7}$

Previous studies analyzed determinants of cancer screening utilization. For instance, it has been shown that an increase of screening procedures was associated with higher age, higher educational level ${ }^{8}$ and being female. $^{7}$ Additionally, health-related factors such as self-rated chronic health conditions ${ }^{9,10}$ and psychological factors are linked to the use of cancer screenings. ${ }^{11}$ Furthermore, previous studies have shown that sociodemographic factors such as country of birth (eg, born in a foreign country), unemployment or lower socioeconomic status are associated with an increased likelihood of dismissing cancer screenings. ${ }^{12,13}$

However, studies examining determinants of postponed cancer screenings are lacking in general - and in particular during the COVID-19 pandemic. The COVID-19 pandemic is accompanied by various challenges for the health and the health care system. However, it is important not to postpone preventive examinations such as cancer screenings during the
COVID-19 pandemic. The aim of this study was to clarify the frequency of postponed cancer screening due to the COVID-19 pandemic and to identify its correlates using cross-sectional data from a nationally representative survey. This knowledge might assist in identifying individuals at risk for postponed cancer screenings.

On the 16th of March 2020 corona-measures such as closing schools were implemented on a national level in Germany. On the 22nd of March additional travel ban and contact regulations followed, which lasted for several weeks. Restrictions were loosened on the 20th of April 2020. Schools gradually reopened in early May (4th May). In May additional measures were loosened (eg, playground reopened, and contact bans loosened). Further restrictions eased in June. However, a spike in COVID-19 cases could lead to a re-implementation of restrictions.

Screening facilities have been closed in several European countries for some time during the COVID-19 pandemic. ${ }^{14-18}$ Moreover, it should be emphasized that elective surgery in hospitals was postponed since March 2020 in Germany. ${ }^{19}$ Additionally, a recently published scoping review determined that studies are missing identifying why outpatient appointments were cancelled during the COVID-19 pandemic in Germany. Nevertheless, a previous study based on nationally representative data demonstrated that perceived access to healthcare was quite good. ${ }^{20}$

\section{Materials and Methods}

\section{Sample}

Data were collected from the COVID-19 Snapshot Monitoring (COSMO), ${ }^{21}$ wave 17 (analytical sample, $\mathrm{n}=974$, aged 18 to 74 years). Individuals answered questions about postponed cancer screenings solely in wave 17 . The COSMO study started in March (3rd and 4th March, wave 1) with weekly follow-up waves until the 26th of May. Subsequently, the survey continued in a 14-day interval. Wave 17 was conducted from the 21 st to 22 nd of July 2020.

The market research company Respondi recruited participants based on an online-panel matching distribution of gender, age and federal state within German population. ${ }^{22}$ 


\section{Dependent Variables}

In concordance to other large cohort studies (like the German Ageing Survey) individuals were initially asked whether they had postponed a cancer screening since March 2020 due to the COVID-19 pandemic (1 "Yes" 2 "No, attended as planned" 3 "No examination pending" 4 "No, other reasons"). Thus, they answered whether they postponed a cancer screening due to the COVID-19 pandemic from March 2020 to late July 2020. We dichotomized the outcome measure $(0=$ no, attended as planned; $1=$ yes, postponed). A pretest $(\mathrm{n}=14$ individuals $)$ confirmed high face validity of dependent variables.

\section{Independent Variables}

Several explanatory variables were included in multiple logistic regression analysis: age group (dividing between: 18 to 29 years; 30 to 49 years; 50 to 64 years; 65 years and over), sex (women; men), mar$\mathrm{ried} /$ in a relationship (no; yes), living status (living alone; $\geq 2$ individuals in household), self-employment (no; yes), educational level ( $\leq 9$ years; $\geq 10$ years, but without general qualification for university entrance; $\geq$ 10 years, including general qualification for university entrance), town size (municipality/small town (120.000 inhabitants); medium sized town (20.001100.000 inhabitants); small city (100.001-500.000 inhabitants); big city (> 500.000 inhabitants)), region (East Germany; West Germany), the COVID-19 cases/ 100,000 population in the federal state of the participant (at the time of data collection: below median; above median), and the presence of at least one chronic condition (no; yes).

Moreover, affect regarding to the COVID-19 disease was assessed, consisting of seven items. For example, items were: "For me, the new type of corona virus is ..." "Spreading slowly" (1) to "spreading quickly" (7) or "inflated in media" (1) to "not given enough attention in media" (7). The score was computed by averaging items. In our study, Cronbach's alpha was 0.78. Furthermore, the presumed severity of COVID-19 disease was quantified ("How do you assess an infection with the novel corona virus for yourself?" (from $1=$ completely harmless to $7=$ extremely dangerous)).

\section{Statistical Analysis}

Sample characteristics for our analytical sample were computed stratified by status of postponement of cancer screenings. Subsequently, we performed multiple logistic regressions to determine associated factors of postponed cancer screenings due to the COVID-19 pandemic. Statistical significance was established at $\mathrm{p}<0.05$. Statistical analyses were conducted using Stata 16.0 (Stata Corp., College Station, Texas).

We also checked for multicollinearity. Since the highest variance inflation factor (VIF) was 1.72 (mean VIF was 1.34), it can be concluded that multicollinearity is not a threat.

\section{Results}

\section{Sample Characteristics}

Sample characteristics (analytical sample with $\mathrm{n}=974$ individuals, average age $=45.9$ years, SD: 16.5 years, 18 to 74 years; $51.1 \%$ female) are shown in Table 1. Bivariate analysis showed that the dependent variable was associated with gender, age group, chronic diseases, affect regarding COVID-19, and presumed severity of COVID19. Further details are displayed in Table 1.

Figure 1 shows the frequency of postponed cancer screenings. In summary, $11.3 \%$ of individuals postponed cancer screenings between March and July 2020 due to the COVID-19 pandemic. Whereas $88.7 \%$ of participants did not report postponed screenings ("no, attended as planned": 13.2\%; "no, examining pending": 71.7\%; "no, other reasons": $3.8 \%)$.

\section{Regression Analysis}

Multiple logistic regressions with postponed cancer screenings since March 2020 due to the COVID-19 pandemic as outcome measure $(0=$ no, attended as planned, 1 = postponed) are depicted in Table 2 . Regressions revealed that the likelihood of postponed cancer screening was positively associated with higher affect regarding COVID-19 (OR: 1.65, 95\% CI: 1.16 2.35), whereas it was negatively associated with younger age (eg, 18 to 29 years, OR: $0.17,95 \% \mathrm{CI}$ : $0.05-0.64$, compared to individuals 30 to 49 years).

In a supplementary analysis (Supplementary Table 1), we used multinomial logistic regressions with the base outcome "Yes, postponed cancer screenings". Overall, 
Table I Sample Characteristics (Wave 17, with n=974 Individuals)

\begin{tabular}{|c|c|c|c|c|c|}
\hline & \multicolumn{5}{|c|}{ Postponed Cancer Screenings } \\
\hline & $\begin{array}{l}\text { Yes, Postponed } \\
\text { Cancer Screenings }\end{array}$ & $\begin{array}{l}\text { No, Attended as } \\
\text { Planned }\end{array}$ & $\begin{array}{l}\text { No Examining } \\
\text { Pending }\end{array}$ & No, Other Reasons & p-value \\
\hline & Mean $(\mathrm{SD}) / \mathrm{n}(\%)$ & Mean (SD)/n (\%) & Mean $(\mathrm{SD}) / \mathrm{n}(\%)$ & Mean (SD)/n (\%) & \\
\hline $\begin{array}{l}\text { Sex } \\
\qquad \text { Male } \\
\text { Female }\end{array}$ & $\begin{array}{l}40(8.4 \%) \\
70(14.1 \%)\end{array}$ & $\begin{array}{l}62(13.0 \%) \\
67(13.4 \%)\end{array}$ & $\begin{array}{l}358(75.2 \%) \\
340(68.3 \%)\end{array}$ & $\begin{array}{l}16(3.4 \%) \\
21(4.2 \%)\end{array}$ & 0.03 \\
\hline $\begin{array}{l}\text { Age category } \\
18 \text { to } 29 \text { years } \\
30 \text { to } 49 \text { years } \\
50 \text { to } 64 \text { years } \\
65 \text { years and over }\end{array}$ & $\begin{array}{l}4(2.1 \%) \\
54(15.4 \%) \\
35(13.0 \%) \\
17(10.3 \%)\end{array}$ & $\begin{array}{l}16(8.5 \%) \\
38(10.9 \%) \\
40(14.8 \%) \\
35(21.2 \%)\end{array}$ & $\begin{array}{l}168(88.9 \%) \\
242(69.1 \%) \\
182(67.4 \%) \\
106(64.3 \%)\end{array}$ & $\begin{array}{l}\text { I }(0.5 \%) \\
16(4.6 \%) \\
13(4.8 \%) \\
7(4.2 \%)\end{array}$ & $<0.001$ \\
\hline $\begin{array}{l}\text { Children under } 18 \text { years: } \\
\text { No } \\
\text { Yes }\end{array}$ & $\begin{array}{l}75(10.4 \%) \\
35(13.9 \%)\end{array}$ & $\begin{array}{l}96(13.3 \%) \\
33(13.1 \%)\end{array}$ & $\begin{array}{l}523(72.4 \%) \\
175(69.4 \%)\end{array}$ & $\begin{array}{l}28(3.9 \%) \\
9(3.6 \%)\end{array}$ & 0.51 \\
\hline $\begin{array}{l}\text { Education } \\
\text { up to } 9 \text { years/ } 10 \text { years and } \\
\text { more (without general } \\
\text { qualification for university } \\
\text { entrance) } \\
10 \text { years and more (with } \\
\text { general qualification for } \\
\text { university entrance) }\end{array}$ & $\begin{array}{l}59(13.3 \%) \\
51(9.6 \%)\end{array}$ & $\begin{array}{l}61(13.8 \%) \\
68(12.8 \%)\end{array}$ & $\begin{array}{l}305(68.8 \%) \\
393(74.0 \%)\end{array}$ & $\begin{array}{l}18(4.1 \%) \\
19(3.6 \%)\end{array}$ & 0.24 \\
\hline $\begin{array}{l}\text { Town size } \\
\text { Municipality/small town } \\
(I-20.000) \\
\text { Medium sized town }(20.00 \mathrm{I}- \\
\text { I00.000) } \\
\text { Small city (I00.00I-500.000) } \\
\text { Big city }(>500.000)\end{array}$ & $\begin{array}{l}45 \text { (II.2\%) } \\
23 \text { (9.6\%) } \\
21 \text { (I4.8\%) } \\
21 \text { (1I.1\%) }\end{array}$ & $\begin{array}{l}57(14.2 \%) \\
32(13.3 \%) \\
12(8.5 \%) \\
28(14.7 \%)\end{array}$ & $\begin{array}{l}282(70.1 \%) \\
180(75.0 \%) \\
102(71.8 \%) \\
134(70.5 \%)\end{array}$ & $\begin{array}{l}\text { I8 (4.5\%) } \\
5(2.1 \%) \\
7(4.9 \%) \\
7(3.7 \%)\end{array}$ & 0.48 \\
\hline $\begin{array}{l}\text { Region } \\
\text { Western Germany } \\
\text { Eastern Germany }\end{array}$ & $\begin{array}{l}90(11.0 \%) \\
20(12.7 \%)\end{array}$ & $\begin{array}{l}110(13.5 \%) \\
19(12.1 \%)\end{array}$ & $\begin{array}{l}583(71.4 \%) \\
115(73.3 \%)\end{array}$ & $\begin{array}{l}34(4.1 \%) \\
3(1.9 \%)\end{array}$ & 0.50 \\
\hline $\begin{array}{l}\text { Cases/ } / 00,000 \text { population } \\
\text { Below median } \\
\text { Above median }\end{array}$ & $\begin{array}{l}54(11.5 \%) \\
56(11.1 \%)\end{array}$ & $\begin{array}{l}54(11.5 \%) \\
75(14.8 \%)\end{array}$ & $\begin{array}{l}340(72.7 \%) \\
358(70.7 \%)\end{array}$ & $\begin{array}{l}20(4.3 \%) \\
17(3.4 \%)\end{array}$ & 0.44 \\
\hline $\begin{array}{l}\text { Relationship/Marriage } \\
\text { No } \\
\text { Yes }\end{array}$ & $\begin{array}{l}34(10.1 \%) \\
76(11.9 \%)\end{array}$ & $\begin{array}{l}4 \mid(12.2 \%) \\
88(13.8 \%)\end{array}$ & $\begin{array}{l}249 \text { (73.9\%) } \\
449(70.5 \%)\end{array}$ & $\begin{array}{l}13(3.9 \%) \\
24(3.8 \%)\end{array}$ & 0.69 \\
\hline $\begin{array}{l}\text { Living situation } \\
\text { Living alone } \\
\text { At least } 2 \text { individuals in the } \\
\text { same household }\end{array}$ & $\begin{array}{l}30(11.9 \%) \\
80(11.1 \%)\end{array}$ & $\begin{array}{l}31(12.3 \%) \\
98(13.6 \%)\end{array}$ & $\begin{array}{l}181(71.5 \%) \\
517(71.7 \%)\end{array}$ & $\begin{array}{l}\text { II (4.3\%) } \\
26(3.6 \%)\end{array}$ & 0.89 \\
\hline $\begin{array}{l}\text { Migration background: } \\
\text { No } \\
\text { Yes }\end{array}$ & $\begin{array}{l}94(11.4 \%) \\
16(10.6 \%)\end{array}$ & $\begin{array}{l}110(13.4 \%) \\
19(12.6 \%)\end{array}$ & $\begin{array}{l}589(71.6 \%) \\
109(72.2 \%)\end{array}$ & $\begin{array}{l}30(3.6 \%) \\
7(4.6 \%)\end{array}$ & 0.93 \\
\hline
\end{tabular}

(Continued) 
Table I (Continued).

\begin{tabular}{|c|c|c|c|c|c|}
\hline & \multicolumn{5}{|c|}{ Postponed Cancer Screenings } \\
\hline & $\begin{array}{l}\text { Yes, Postponed } \\
\text { Cancer Screenings }\end{array}$ & $\begin{array}{l}\text { No, Attended as } \\
\text { Planned }\end{array}$ & $\begin{array}{l}\text { No Examining } \\
\text { Pending }\end{array}$ & No, Other Reasons & p-value \\
\hline $\begin{array}{l}\text { Self-employment } \\
\text { No } \\
\text { Yes }\end{array}$ & $\begin{array}{l}97 \text { (I I.0\%) } \\
13(14.3 \%)\end{array}$ & $\begin{array}{l}116(13.1 \%) \\
13(14.3 \%)\end{array}$ & $\begin{array}{l}638(72.3 \%) \\
60(65.9 \%)\end{array}$ & $\begin{array}{l}32(3.6 \%) \\
5(5.5 \%)\end{array}$ & 0.55 \\
\hline $\begin{array}{l}\text { Chronic disease } \\
\text { No } \\
\text { Yes }\end{array}$ & $\begin{array}{l}61(10.0 \%) \\
49(13.4 \%)\end{array}$ & $\begin{array}{l}70(11.5 \%) \\
59(16.2 \%)\end{array}$ & $\begin{array}{l}46 \text { I (75.7\%) } \\
237 \text { (64.9\%) }\end{array}$ & $\begin{array}{l}17(2.8 \%) \\
20(5.5 \%)\end{array}$ & $<0.01$ \\
\hline $\begin{array}{l}\text { Affect regarding COVID-I9 } \\
\text { (higher values correspond to } \\
\text { higher affect regarding COVID- } \\
\text { 19) }\end{array}$ & $4.5(\mathrm{I} . \mathrm{I})$ & $4.0(0.9)$ & $4.1(1.0)$ & $4.2(1.2)$ & $<0.001$ \\
\hline $\begin{array}{l}\text { Presumed severity of COVID- } \\
19 \text { disease (from I to } 7 \text {; higher } \\
\text { values correspond to higher } \\
\text { severity) }\end{array}$ & $4.7(1.4)$ & $4.4(1.6)$ & $4.1(1.5)$ & $4.6(1.9)$ & $<0.001$ \\
\hline
\end{tabular}

Abbreviations: SD, standard deviation.

these findings remained comparable. Moreover, in a further supplementary analysis (Supplementary Table 2), multiple logistic regressions with postponed cancer screenings since March 2020 due to the COVID-19 pandemic as outcome measure $(0=$ no, attended as planned, 1 = postponed) were performed among individuals aged 50 years and over (since most cancer screenings are performed among older adults). Please see Supplementary Table 2 for further details.

\section{Discussion}

Based on nationally representative cross-sectional data, the aim of this study was to clarify the frequency of postponed cancer screening due to the COVID-19 pandemic and to identify its correlates. Overall, more than $10 \%$ of the individuals postponed cancer screenings since between March and July 2020 due to the COVID-19 pandemic, particularly women and individuals aged 30 to 49 years. It should be noted that approximately $46 \%$ postponed their cancer screening (when we exclusively compare individuals who postponed cancer screenings and individuals who did not attend as planned).

Regressions showed that the likelihood of postponed cancer screening was positively associated with higher affect regarding COVID-19, whereas it was negatively associated with younger age.

Differences in the likelihood of postponed cancer screening between individuals aged 18 to 29 years and individuals aged 30 to 49 years may be determined by a low number of cancer screenings offered to individuals aged 18 to 29 years. For example, in this young age group health insurances in Germany reimburse solely one annual genital examination (including pap smear) for women aged 20 years and older (to detect cervical cancer). However, in older age, various additional cancer screening procedures are fully paid by health insurances.

Higher affect regarding COVID-19 was associated with postponed cancer screenings in our study. This appears to be plausible since negative affect regarding COVID-19 is linked to anxiety. ${ }^{23}$ A previous review showed that factors such as anxiety or cancer worry are 


\section{Postponed cancer screenings}

80

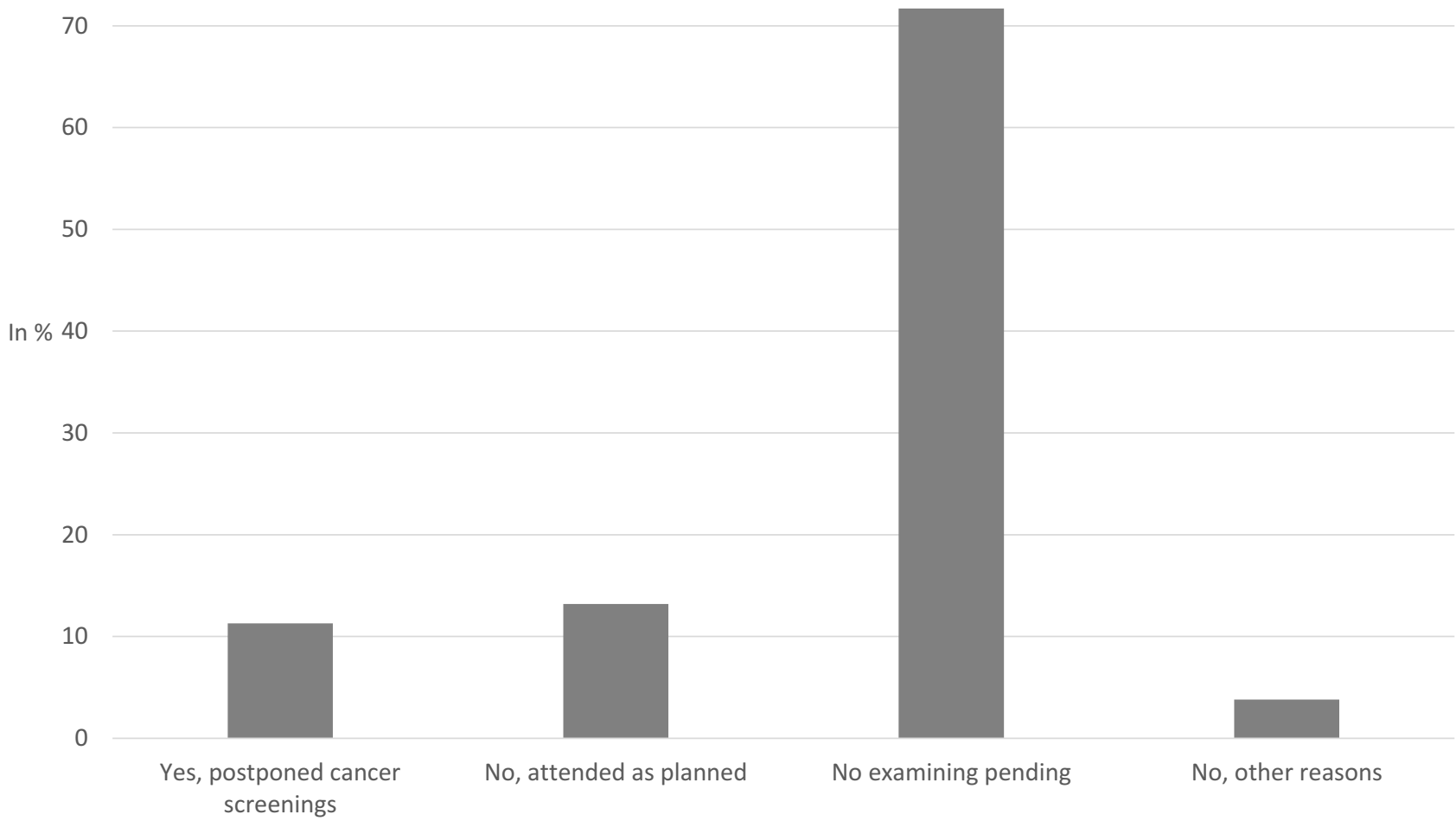

Figure I Postponed cancer screenings.

clearly linked to cancer screening behavior. ${ }^{24}$ However, these existing findings differ in direction. ${ }^{24}$ Thus, future research is required to clarify the link between affect regarding COVID-19 and postponed cancer screenings during the COVID-19 pandemic.

It is worth noting that the decision to postpone intended cancer screenings can additionally be caused by balancing effects of cancer screenings and potential costs, particularly for individuals in poor health. Consequently, delaying cancer screenings can make sense for certain groups to avoid serious health consequences caused by COVID-19.

A strength of this study is that it is the first nationwide study identifying the frequency and its determinants of postponed cancer screenings during the COVID-19 pandemic. Data were derived from general adult population. However, individuals aged 75 years and above were not included and should be examined in future studies. Due to data availability differentiation between types of cancer screening is not possible. Nevertheless, we provide first insights into determinants of postponed cancer screenings in general. The cross-sectional study design is a limitation because it is difficult to draw causal conclusions. Thus, future longitudinal studies are required to clarify the directionality.

\section{Conclusion}

Study findings showed that one out of ten individuals postponed cancer screenings during the COVID-19 pandemic. We determined two correlates of them (age and affect regarding COVID-19). Individuals with an increased 
Table 2 Determinants of Postponed Cancer Screenings ( 0 = No, Not Postponed; I = Yes, Postponed) Due to the COVID- 19 Pandemic Since March 2020. Findings of Multiple Logistic Regressions

\begin{tabular}{|c|c|}
\hline Independent Variables & Postponed Cancer Screenings \\
\hline Gender: Female (Ref.: Male) & $\begin{array}{c}1.26 \\
(0.70-2.27)\end{array}$ \\
\hline Age category: - 18 to 29 years (Ref.: 30 to 49 years) & $\begin{array}{c}0.17^{* *} \\
(0.05-0.64)\end{array}$ \\
\hline - 50 to 64 years & $\begin{array}{c}0.49 \\
(0.24-1.02)\end{array}$ \\
\hline - 65 years and over & $\begin{array}{c}0.38^{*} \\
(0.16-0.89)\end{array}$ \\
\hline Children (under 18 years): Yes (Ref.: Absence of children under 18 years) & $\begin{array}{c}1.17 \\
(0.56-2.46)\end{array}$ \\
\hline Education: General qualification for university entrance (Ref.: absence of qualification for university entrance) & $\begin{array}{c}0.64 \\
(0.35-1.19)\end{array}$ \\
\hline Town size: - Medium sized town (20.00I-100.000) (Ref.: municipality/small town (I-20.000)) & $\begin{array}{c}0.95 \\
(0.45-1.96)\end{array}$ \\
\hline - Small city $(\mathrm{I} 00.00 \mathrm{I}-500.000)$ & $\begin{array}{c}2.45^{*} \\
(1.00-5.99)\end{array}$ \\
\hline - Big city $(>500.000)$ & $\begin{array}{c}1.05 \\
(0.48-2.29)\end{array}$ \\
\hline Region: East Germany (Ref.: West Germany) & $\begin{array}{c}0.93 \\
(0.39-2.23)\end{array}$ \\
\hline Cases/I00,000 population: Above median (Ref.: below median) & $\begin{array}{c}0.69 \\
(0.36-1.32)\end{array}$ \\
\hline Relationship/Marriage: Yes (Ref.: no partnership/marriage) & $\begin{array}{c}0.96 \\
(0.4 I-2.23)\end{array}$ \\
\hline Living situation: At least 2 individuals in the same household (Ref.: living alone) & $\begin{array}{c}0.89 \\
(0.36-2.18)\end{array}$ \\
\hline Migration background: Yes (Ref.: no migration background) & $\begin{array}{c}1.24 \\
(0.52-2.92)\end{array}$ \\
\hline Self-employment: Yes (Ref.: not self-employed) & $\begin{array}{c}0.99 \\
(0.40-2.46)\end{array}$ \\
\hline Chronic disease: Yes (Ref.: no chronic diseases) & $\begin{array}{c}1.02 \\
(0.55-1.89)\end{array}$ \\
\hline Affect regarding COVID-19 (higher values correspond to higher affect regarding COVID-19) & $\begin{array}{c}1.65 * * \\
(1.16-2.35)\end{array}$ \\
\hline Presumed severity of COVID-19 disease (higher values correspond to higher severity) & $\begin{array}{c}0.93 \\
(0.74-1.18)\end{array}$ \\
\hline Observations & 239 \\
\hline
\end{tabular}

Notes: Odds ratios are reported; $95 \%$ confidence intervals in parentheses; $* * \mathrm{p}<0.01,{ }^{*} \mathrm{p}<0.05$.

Abbreviation: Ref, reference category. 
likelihood of postponed cancer screenings should be specifically addressed.

\section{Abbreviations}

COSMO, COVID-19 Snapshot Monitoring in Germany; COVID-19, coronavirus disease 2019; Ref, reference category; SD, standard deviation; OR, odds ratio; CI, confidence interval.

\section{Data Sharing Statement}

Data are not publicly available but interested parties may contact the authors for more information (Permission granted by PIs of COSMO study).

\section{Ethics Approval and Informed Consent}

Informed consent was obtained from all individual participants included in the study. All procedures performed in the COSMO studies involving human participants were in accordance with the ethical standards of the University of Erfurt institutional research committee (\#202000302) and with the 1964 Helsinki Declaration and its later amendments or comparable ethical standards.

\section{Acknowledgments}

Germany's COVID-19 Snapshot Monitoring (COSMO) is a joint project of the University of Erfurt (Cornelia Betsch [PI], Lars Korn, Philipp Sprengholz, Philipp Schmid, Lisa Felgendreff, Sarah Eitze), the Robert Koch Institute (RKI; Lothar H. Wieler, Patrick Schmich), the Federal Centre for Health Education (BZgA; Heidrun Thaiss, Freia De Bock), the Leibniz Centre for Psychological Information and Documentation (ZPID; Michael Bosnjak), the Science Media Center (SMC; Volker Stollorz), the Bernhard Nocht Institute for Tropical Medicine (BNITM; Michael Ramharter), and the Yale Institute for Global Health (Saad Omer).

\section{Author Contributions}

All authors significantly contributed to conceptualization; A.H. contributed to methodology/formal analysis; A. H. contributed to writing - original draft preparation; All authors substantially contributed to writing - review and editing; H.-H.K contributed to supervision. All authors have agreed on the journal to which the article will be submitted. Moreover, all authors reviewed and agreed on all versions of the article before submission and during revision. All authors agree to take responsibility and be accountable for the contents of the article.

\section{Funding}

DFG 3970/11-1; further funding via BZgA, RKI, ZPID, University of Erfurt (no funding numbers). The funders had no role in study design, data collection and analysis, decision to publish, or preparation of the manuscript.

\section{Disclosure}

The authors report no conflicts of interest in this work.

\section{References}

1. Jemal A, Siegel R, Ward E, et al. Cancer statistics, 2008. CA Cancer J Clin. 2008;58(2):71-96. doi:10.3322/CA.2007.0010

2. Robert-Koch-Institut. Krebs in Deutschland 2007/2008. 8th ed. Berlin: RKI; 2012.

3. Bertz J, Dahm S, Haberland J, Kraywinkel K, Kurth B-M WU. Verbreitung von Krebserkrankungen in Deutschland. Berlin: RKI; 2010.

4. Wilson J, Jungner Y. Principles and Practices of Screening for Disease. Geneva: World Health Organization; 1968.

5. Gemeinsamer Bundesausschuss. Richtlinie des Gemeinsamen Bundesausschusses über die Früherkennung von Krebserkrankungen (Krebsfrüherkennungs-Richtlinie/KFE-RL); 2020.

6. Bundesministerium für Gesundheit. Krebsfrüherkennung; 2019. Available from: https://www.bundesgesundheitsministerium.de/krebs frueherkennung.html. Accessed July 1, 2021.

7. Spuling SM, Ziegelmann JP, Wünsche J. Was tun wir für unsere Gesundheit? Gesundheitsverhalten in der zweiten Lebenshälfte. In: Mahne K, Wolff JK, Simonson J, Tesch-Römer C, editors. Altern im Wandel: Zwei Jahrzehnte Deutscher Alterssurvey (DEAS). Berlin: Deutsches Zentrum für Altersfragen (DZA); 2016:141-160.

8. Starker A, $\mathrm{Sa}$ A-C. Inanspruchnahme von Krebsfrüherkennungsuntersuchungen. Bundesgesundheitsblatt. 2013;56(5-6):858-867. doi:10.1007/s00103-012-1655-4

9. Gorin SS, Heck JE. Cancer screening among Latino subgroups in the United States. Prev Med. 2005;40(5):515-526. doi:10.1016/j. ypmed.2004.09.031

10. Hsia J, Kemper E, Kiefe C, et al. The importance of health insurance as a determinant of cancer screening: evidence from the Women's Health Initiative. Prev Med. 2000;31(3):261-270. doi:10.1006/ pmed.2000.0697

11. Hajek A, Bock JO, König HH. The role of general psychosocial factors for the use of cancer screening-Findings of a populationbased observational study among older adults in Germany. Cancer Med. 2017;6(12):3025-3039. doi:10.1002/cam4.1226

12. Bongaerts TH, Büchner FL, Middelkoop BJ, Guicherit OR, Numans ME. Determinants of (non-) attendance at the Dutch cancer screening programmes: a systematic review. J Med Screen. 2019;27 (3):0969141319887996. doi:10.1177/0969141319887996

13. Svihrova V, Kocsis L, Svihra Jr J, Szaboova V. Barriers to the Cervical Cancer Screening in the Northern Slovakia; 2020.

14. Amit M, Tam S, Bader T, Sorkin A, Benov A. Pausing cancer screening during the severe acute respiratory syndrome coronavirus 2pandemic: should we revisit the recommendations? Eur J Cancer. 2020;134:86. doi:10.1016/j.ejca.2020.04.016

15. Kregting LM, Kaljouw S, de Jonge L, et al. Effects of cancer screening restart strategies after COVID-19 disruption. $\mathrm{Br} J$ Cancer. 2021;124(1):1-8. doi:10.1038/s41416-020-01171-2 
16. Mahase E. Covid-19: cancer Research urges mass testing to enable care to continue during pandemic. BMJ. 2020;369:m1561.

17. Vanni G, Pellicciaro M, Materazzo M, Palombi L, Buonomo OC. Breast cancer diagnosis in coronavirus-era: alert from italy. Front Oncol. 2020;10:938. doi:10.3389/fonc.2020.00938

18. Vrdoljak E, Sullivan R, Lawler M. Cancer and coronavirus disease 2019; how do we manage cancer optimally through a public health crisis? Eur $J$ Cancer. 2020;132:98-99. doi:10.1016/j. ejca.2020.04.001

19. Osterloh F. Coronavirus:Krankenhäuser verschieben planbare Eingriffe. Dtsch Arztebl. 2020;117(12):A575-A577.

20. Hajek A, De Bock F, Wieler LH, Sprengholz P, Kretzler B, König $\mathrm{H}-\mathrm{H}$. Perceptions of Health Care Use in Germany during the COVID-19 Pandemic. Int J Environ Res Public Health. 2020;17 (24):9351. doi:10.3390/ijerph17249351
21. Betsch C, Wieler LH, Habersaat K. Monitoring behavioural insights related to COVID-19. Lancet. 2020;395(10232):1255-1256. doi:10.1016/S0140-6736(20)30729-7

22. Münnich R, Gabler S. 2012: Stichprobenoptimierung und Schätzung in Zensus 2011. Vol. 21. Wiesbaden: Statistisches Bundesamt; 2012.

23. Watson D, Clark LA, Carey G. Positive and negative affectivity and their relation to anxiety and depressive disorders. J Abnorm Psychol. 1988;97(3):346. doi:10.1037/0021-843X.97.3.346

24. Consedine NS, Magai C, Krivoshekova YS, Ryzewicz L, Neugut AI. Fear, anxiety, worry, and breast cancer screening behavior: a critical review. Cancer Epidemiol Biomarkers Prev. 2004;13(4):501-510.
Risk Management and Healthcare Policy

\section{Publish your work in this journal}

Risk Management and Healthcare Policy is an international, peerreviewed, open access journal focusing on all aspects of public health, policy, and preventative measures to promote good health and improve morbidity and mortality in the population. The journal welcomes submitted papers covering original research, basic science, clinical \& epidemiological studies, reviews and evaluations,

\section{Dovepress}

guidelines, expert opinion and commentary, case reports and extended reports. The manuscript management system is completely online and includes a very quick and fair peer-review system, which is all easy to use. Visit http://www.dovepress.com/testimonials.php to read real quotes from published authors. 